\title{
Building stone used in architectural objects in the town of Wieluń
}

\author{
Adam Śpiewak \\ Wroctaw University of Science and Technology, Faculty of Geoengineering, Mining and Geology, \\ ul. Na Grobli 15, 50-421 Wroctaw; \\ e-mail:adam.spiewak@o2.pl
}
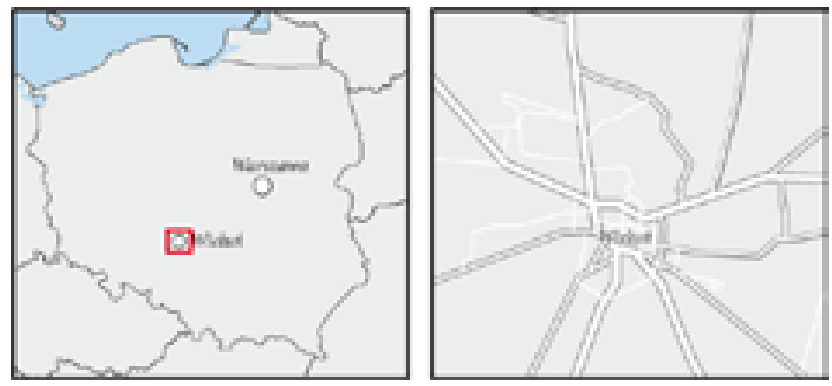

Abstract: The architectural space of the center of Wielun and chosen objects located in the town were analyzed. Research was carried out on the identification of building stones in this particular area. On the basis of the research, it is possible to find over fifty kinds of various stone materials, including sedimentary, igneous and metamorphic rocks. These were classified and counted. For the first time, a coefficient of Used Kinds of Stone in architectural Objects (UKSO) was suggested. Its purpose was to show, from the engineering point of view, the amount of the stone in urban architecture. The most interesting stone pictures display their variations in color, structure and texture. The gathered results confirm their geological inheritance and increase the tourist attractiveness of the town.

Key words: building stone, geotourism, geology, architecture, Wieluń

\section{Introduction}

Since the $13^{\text {th }}$ century, the inhabitants of the town of Wielun used natural stones as building materials on a large scale. Stone was a cheap and widely available raw material. Moreover, it was much more resistant than wood. Throughout the centuries, rocks have not kept up with the more advanced and durable materials such as industry ceramics, steel or glass. A fundamental factor leading to an increase in the usage of stone in Wielun's buildings was that the town possessed limestone and sandstones quarries. They were located nearby, due to the geological structure of this area (Janus, Obarowska, 2011). This land belongs to the KrakówCzęstochowa-Wielun Upland, where numerous carbonate rocks outcrops can be found. This short distance, up to ca. 30 kilometres, from the limestone and sandstone quarries to the town of Wielun, made the cost of the transport of the stones low. The traditional rock material used in the town and neighborhood was the Upper- and Middle Jurassic limestone and, to a small degree, the Middle Jurassic sandstone. The preserved medieval town walls built from the aforementioned limestone, forming one of the longest limestone fortifications in Poland, with a length of about 270 meters.

The type, size and character of the rocks used in the architectural objects have changed over centuries. Nowadays, local rock material lost its paramount meaning as a construction component in buildings and kept mainly its decorative and finishing functions (Rodrigues et al., 2011). Exploitation of deposits in old limestone or sandstone quarries was ceased, because of the unprofitable extraction or a lack of resources. These parts of the quarries have stood the test of time until today, in various states. Some of them were naturally reclaimed. Large progress in taking advantage of different kinds and forms of stones was witnessed in Poland from the $19^{\text {th }}$ century's industrial revolution, especially at the turn of $20^{\text {th }}$ and $21^{\text {th }}$ century. This revolves around either Polish or foreign rocks (Rajchel, 2008); influencing the richness of stonework in selected architectural objects of the town. An interesting example of stone materials can be found in the oldest monuments of the town, which in various forms, stood the test of time, as well as the air bombings during the Second World War. Wielun was the first shelled place in Poland in 1939.

\section{Location and geological structure}

Wielun is set in the southwest part of the Łódź Voivodeship. The town is also located at a junction of four physical-geographical Mesoregions: Wielun Upland (the south-middle part of the town) included in the Woźniki-Wieluń Upland, as well as Wieruszów Plateau (the west part), Złoczew Plateau (the north part) and Szczerców Valley (the northeast part), which are a part of the South-Greater Poland Valley (Kondracki, 2002; http://www.um.wielun.pl, 2012). The town is situated in central Poland, on a significant road junction where the main state routes cross. It extends to an area of ca. 16.9 square kilometers. The District and community authorities are located in Wielun.

Rocks in the area of the town came into being during two geological eras: Mesozoic and Cenozoic. The forms from the Mesozoic era appear in the southern part of the town. These are „gezy” - siliceous sedimentary rocks and marl 
limestones of the Middle Jurassic. In the north part of the town, in contrast, there are limestones of the Upper Jurassic. There is a chance that the Kowalski Quarry, located in the southeastern part of the town, could become in the future one of the most interesting geotouristic objects in Wielun. The quarry has the one and only outcrop of Callovian rocks (Janus, Obarowska, 2011) in this area. The second quarry, in the town, is the limestone quarry in Niedzielsko in the northeast part of the town, whose name is taken from the district where it is located. The Cenozoic era is represented by Pleistocene outwash sands and gravels in the middle part of the town, as well as Pleistocene tills, postglacial sands and gravels in the northwest part of the town (http://mapy-geol.pgi. gov.pl, 2011). Appearance of numerous Cenozoic rocks is a result of the influence zone of the Warta Glaciation.

\section{Characteristic of stone materials used in the explored area}

Because of the specific character of this article, the application of stonework-geological language was necessary. For a long time, in the stonework milieu, simplified classification of rocks was used such as ,granites”, „marbles” and sandstones. Despite commercial names, there are also more and more frequently used particular petrographic names, such as quartzite limestone, onyxes or travertine (Zagożdżon, 2009). Sandstones, as the only group of the basic rocks classification, owe their commercial name fully to their petrographic equivalent (Lorenc, Mazurek, 2007). Rocks classified in groups of „granites” and „marbles” differ from each other not only by sort, colour or minerals, but also by physical and chemical properties. Because of these differences, their commercial names in global trade are misleading and inaccurate. For instance, among "granites" often there are not only directly petrographic granites as Strzegom granite, Strzelin granite or Karkonosze granite, but also numerous kinds of magmatic rocks, such as gabbros (e.g. Angola Black), granodiorites (e.g. Kośmin), dioriete monzonite, anorthosite, or metamorphic rocks as gneiss, granite-gneiss, quartzite, migmatite or granulite An analogous situation concerns ,marbles", to which, apart from crystalline marbles (metamorphic rocks), other sedimentary rocks such as travertines, compact limestones (polished), partially crystallized variants of limestones or dolomites, as well as some conglomerates, vein carbonate rocks and serpentines are also classified (Rajchel, 2004). The decorative values of sedimentary rocks, for example, limestones, travertines or conglomerates can very wide. They differ by colour, diversified veins or by the appearance of fossils. Thanks to the aforementioned features, these rocks are not more precious than marbles (Prell, Zagożdżon, 2011). However, carbonate sedimentary rocks often display worse technical parameters than marbles, including their less compressive strength, less endurance in abrasion or bigger absorptivity.

The types of surface textures of the stone materials are diversified. Stone elements of riven, grinded or polished surface texture can be noticed on the examined area (Zagożdżon,
Śpiewak, 2011). Other types of surface textures are hardly ever noticeable. The type of surface texture has a very large influence on the final visual effect of any building, monument or element, as well as on its preservation and maintenance in an appropriate technical condition.

Some of explored places were described in a general manner, due to lack of resources and literature available regarding the origin of each stone material. The scope of this very article does not include urban cemeteries. Because of the great number of different stone building material existing in cemeteries' area, they require a separate publication.

This exploration led to the classification of the building stones used in the researched area. From this point of the article, Chosen rock examples will be described in four main groups, including sandstones, ,granites”, „marbles” and erratics.

\section{Sandstones}

Ferruginous sandstone was the only sandstone exploited in the region in the past. A sandstone quarry is located in the Olewin village - ca. 6,5 kilometers towards the East. The rock comes from the Lower Jurassic or from the Middle Jurassic time, from the Lower Bajocian to be exact (Janus, Obarowska, 2011). The ferruginous sandstone represents the so-called Kościeliskie stratums - highly porous and water-bearing sands and sandstones. The sandstone is specific because of its colour range - from yellow-orange to cherry-brown. It is the most often used sandstone in buildings in the explored area. The Olewin sandstone was mainly formed as stone blocks with riven surface textures. Sometimes, thanks to good mining and geological conditions in the deposit, there was a possibility of getting blocks of large sizes. The Olewin ferruginous sandstone formed the base to build the Virgin Mary's grotto in the Franciscan monastery (Fig. 1). This church is dedicated to the Annunciation of the Virgin Mary. The stone partly survived in remains of the St. Michael's church walls, the parish church in the past. It was destroyed by Nazis in the Second World War. We can also see the ferruginous sandstone (Fig. 2) in the front of the church, dedicated to the Visitation of the Virgin Mary, also known as the Corpus Christi collegiate. It is also present in different stone forms in the Wielun botanical garden.

The Rakowiczki sandstone, exploited in the Rakowice Małe village, belongs to a large group of sandstones, from the region of the Lwówek Sląski town. The rock is classified from the Cretaceous period. The sandstone has a „warm”, yellow colour, with thick stratification, increased by the variable content of iron compounds, for example limonite. The Rakowiczki sandstone, as well as other sandstones from the region of Lwowek Slaski has a certified opinion of the government and in foreign trade. The rocks' main features are excellent physical properties, and the tradition of their exploitation reaches the Middle Ages. The Rakowiczki sandstone was used as outside vertical and horizontal slabs of the January Uprising Heroes monument, as well as in an altar of the Mother of God's seventh shrine - placed on the Corpus Christi collegiate area. 


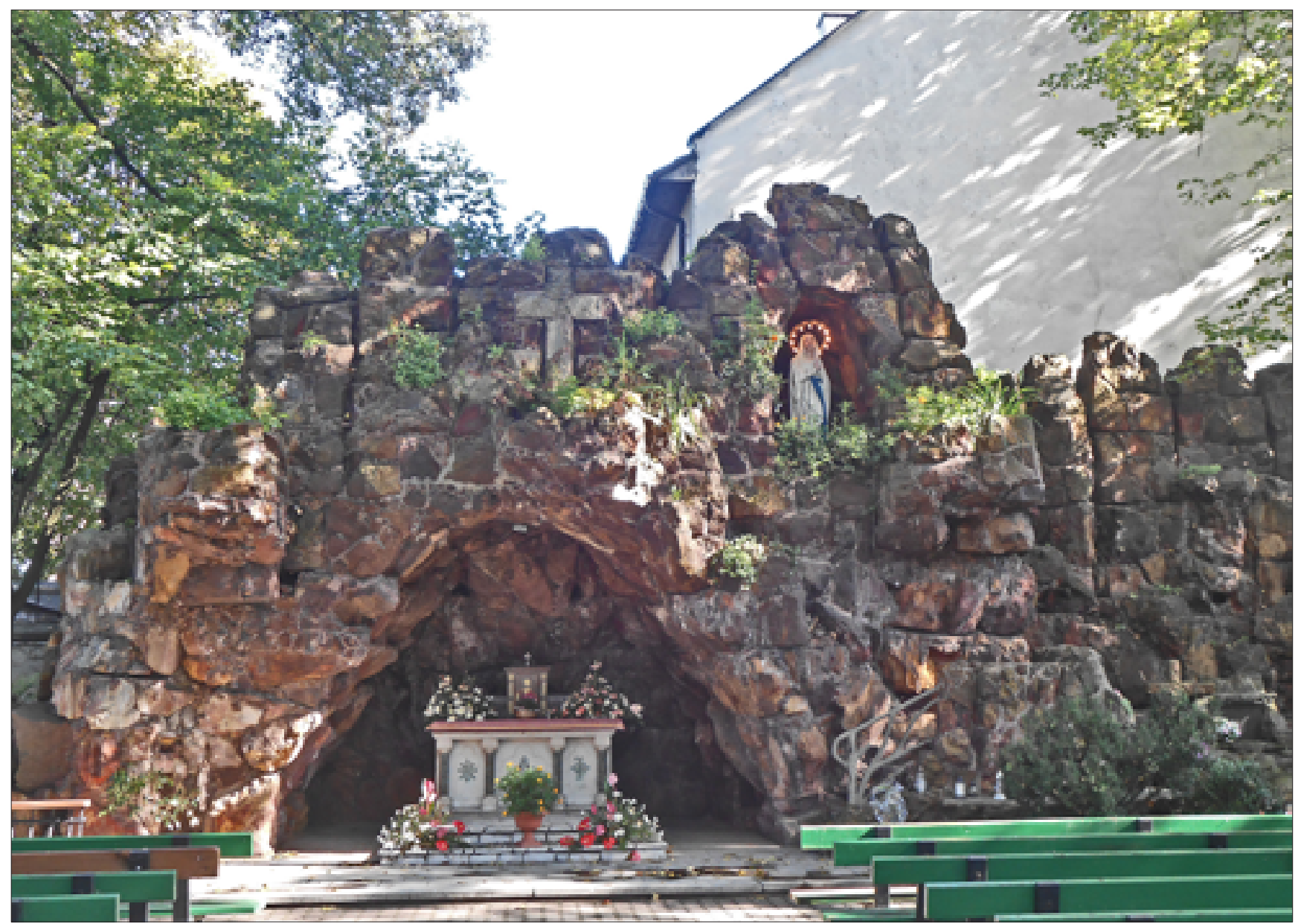

Fig. 1. The Virgin Mary's grotto built of ferruginous sandstone in the Franciscan monastery - general view of the grotto, photo A. Śpiewak

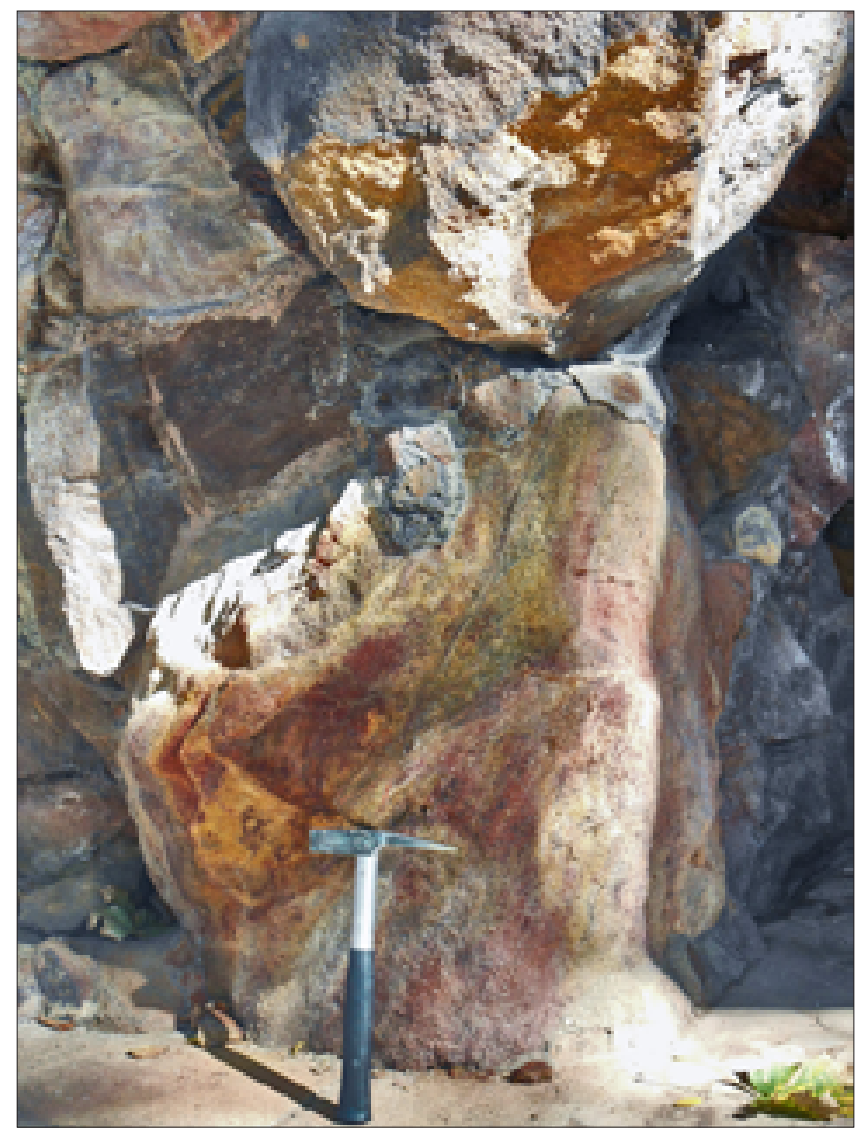

Fig. 2. A block of ferruginous sandstone on the left side of the Virgin Mary's grotto, photo A. Śpiewak

\section{Limestones}

Middle Jurassic limestones (siliceous sedimentary rocks, marl limestones) and Upper Jurassic limestones are very commonly used rocks in the town. The stones dominate in the architecture of the city center, as far as the total volume of the stone material. The Middle Jurassic and Upper Jurassic limestones deposits were exploited either in the town's area or in the nearest neighborhood. The output of the limestone was taken from one of the Kowalski Quarries, near the crossroads of Częstochowska and Polna streets. It was also taken from the quarry in Niedzielsko. Other quarries are located in the distance of ca. 25 kilometers to the southwest from Wielun, in the Działoszyn town area - in the Bobrowniki and Lisowice villages. Among the numerous former quarries, the only active one can be found in the Lisowice village, where the "Lisowice-Wieś" deposit is exploited. The Middle Jurassic and Upper Jurassic limestones are the main building element in Cracow's Gate (Fig. 3), Kalisz's Gate, the town defensive walls, the town hall, the parish church and also, in large post-industrial objects like the „Amerykanka” mill or the „Wielun”" sugar factory. Building elements of 
the limestone in the form of various crushed stone or blocks were discovered. The forementioned stone elements are distinguished by their riven type of surface texture. They rarely happen to have a grinded surface texture. Fossils of the Jurassic fauna are often noticed in the limestones, for example, ammonites (Fig. 4) that can reach even 20 centimeters in diameter.

The Raciszyn limestone is given with the name of ,travertine" in the stonework market, although its origins are different than in the case of calcareous sinter and travertines. Deposits of these „travertines” are exploited in the Eódź Voivodeship, in the area of Działoszyn town, which is located in the distance of ca. Twenty seven kilometers to the southwest from Wielun. We documentedthree deposits, „Raciszyn”, „Raciszyn II” and „Zalesiaki”. The Jurassic limestone shows strong crystallization and changeable porosity or the appearance of caverns. There are three colour variants distinguished - cream, beige and golden. The rocks from Działoszyn have high decorative virtues. The stone displays various types of surface textures (riven, grinded or polished). The Raciszyn limestone is used very often in Wieluń. It was observed inside the facing slabs and flooring slabs, outside the facing stair slabs, rocky blocks and crushed stone. The Raciszyn limestone is placed in St. Stanislaus's church, inside the building of the Wielun's community center, at the base of the commemorative plaque of the Second World War victims, in the planty park and also in the botanical garden (Figs 5, 6).

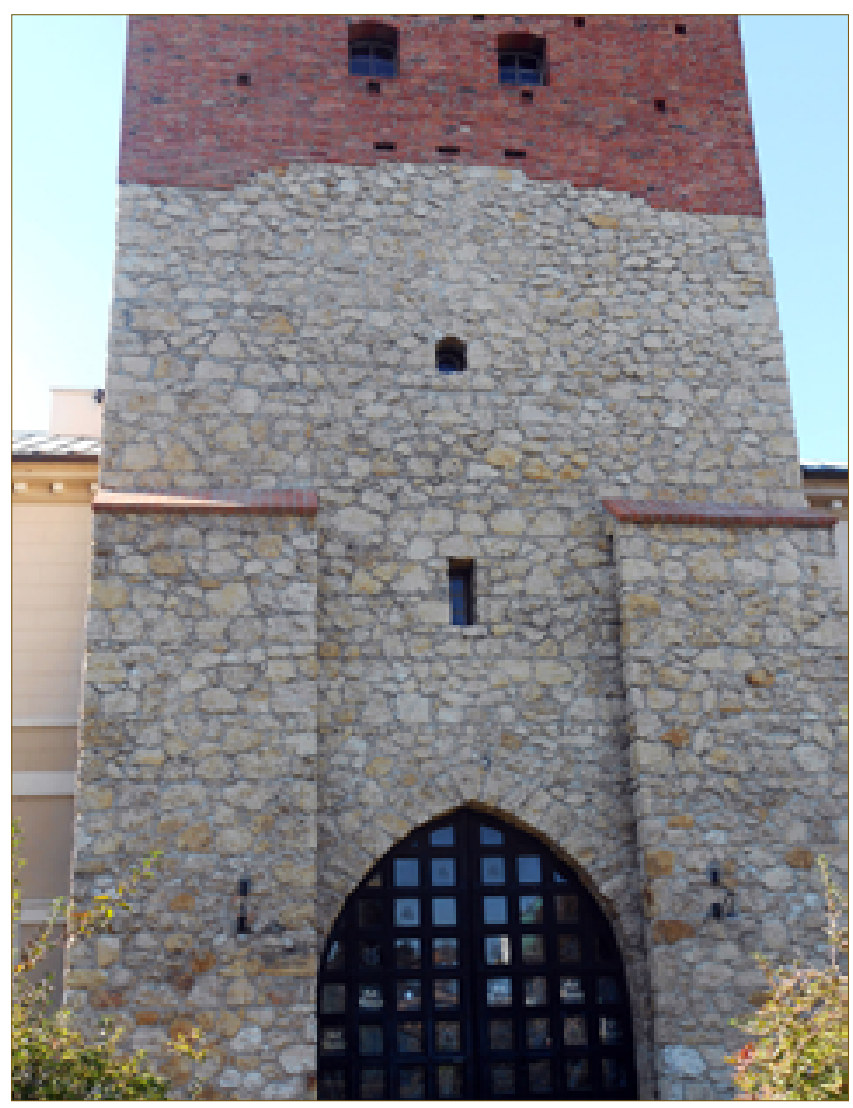

Fig. 3. General view of the Cracow's Gate - cut stone of the Middle and Upper Jurassic limestone, photo A. Śpiewak

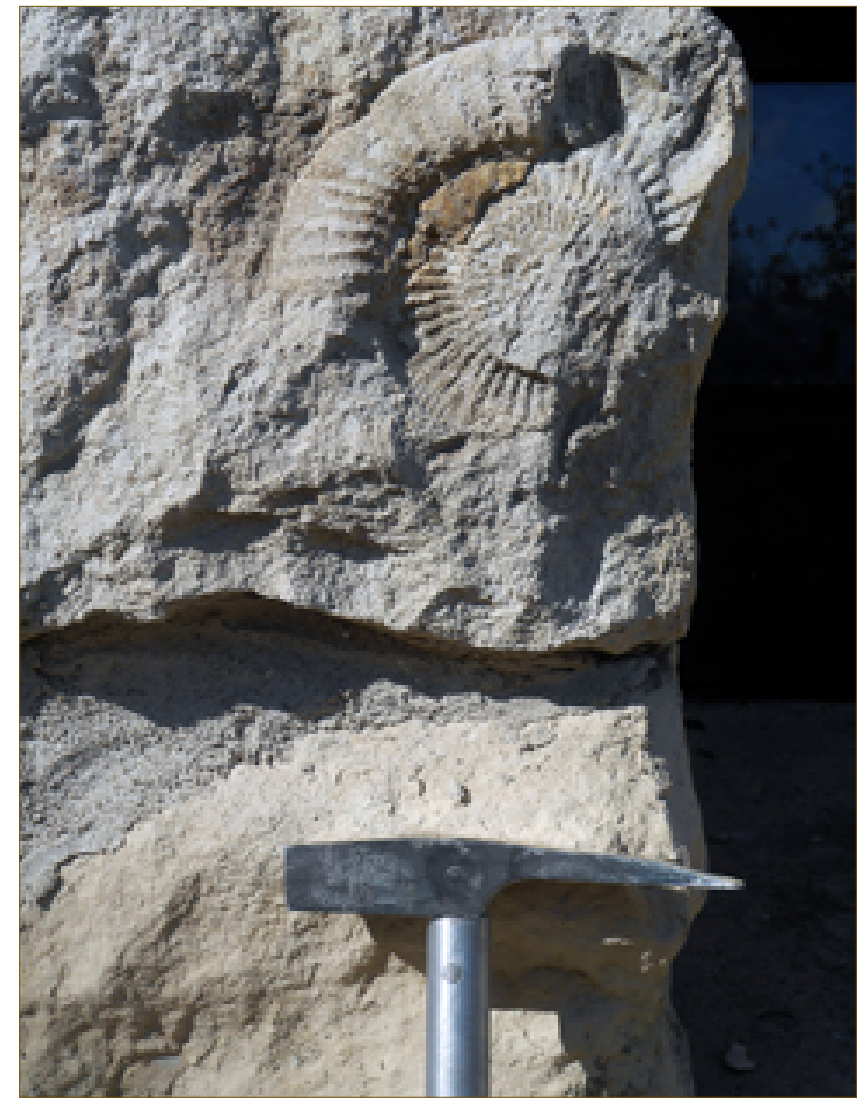

Fig. 4. Fossil ammonite in the Upper Jurassic limestone from the Cracow's Gate, photo A. Śpiewak

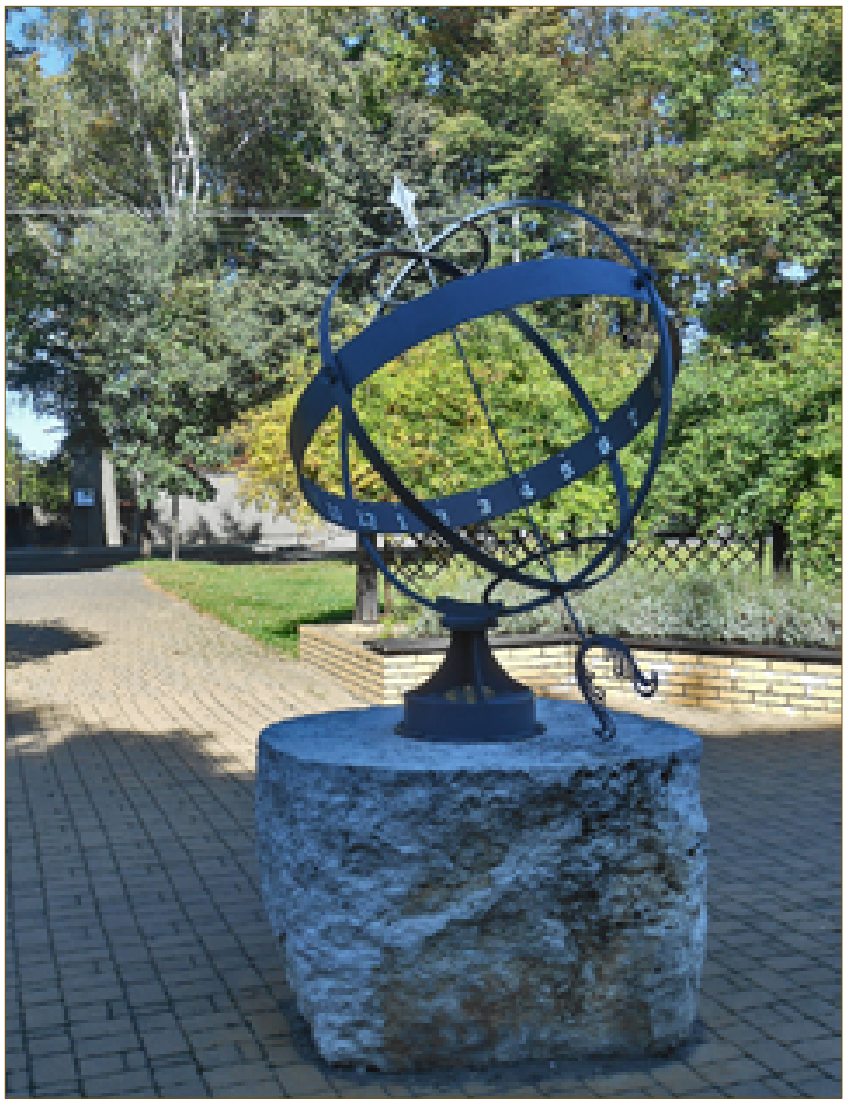

Fig. 5. General view of the sundial in the Wielun Planty Park a rocky block of Raciszyn limestone, photo A. Śpiewak 


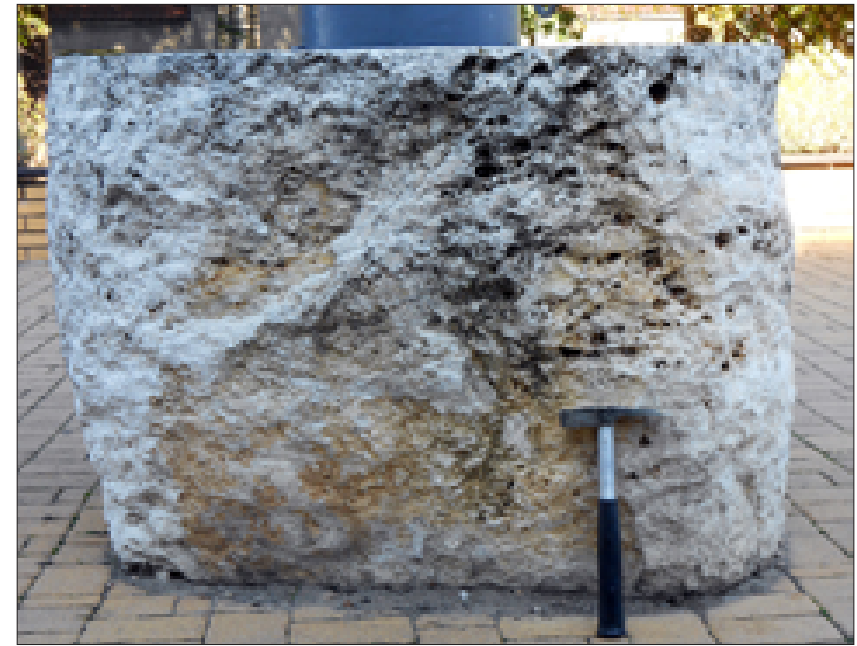

Fig. 6. A block of Raciszyn limestone with a many different caverns, photo A. Śpiewak

\section{Granites}

The Strzegom granite is the most commonly used Polish granite in the explored area. There are various ways granite from Lower Silesia has been used in the architecture of Wieluń. Cobblestone, inside flooring slabs, outside facing slabs and stair slabs, as well as cut stones were made of this kind of stone. The rock has several different types of surface textures, riven, polished or grinded. The Strzegom granite was used in St. Stanislaus's Bishop and Martyr church (Figs 7, 8). It also appears in St. Joseph's church, a parish church (St. Michael's church), in front of a commemorative plaque of a Synagogue and in the bus station building „PKS Wieluń".

The Tranas Red granite is one of the representatives of Swedish granites, although they are rarely observed. The rock is distinguished by its intensive red colour, which can be of the intensity of a cherry. This granite has been used as outside vertical facing slabs, flagstones and outside stair slabs. The Tranas Red granite is mainly used in Pope John Paul II's monument and, to a significantly smaller degree, on the St. Stanislaus church square.

Quartz diorite and quartz monzodiorite of Przedborowa are known as the only Polish „syenite”, found in the researched area. Black rocks from the Przedborowa quarry are well known because of their colour range - from dark grey to black, with small white crystals of feldspars. The Przedborowa quartz diorite and quartz monzodiorite are exploited in Lower Silesia. The stone was used as inside flooring slabs and facing slabs of the bus station „PKS Wieluń” (Figs 9, 10), as well as in the building of Bank Pekao - Wieluń branch. The rock has only a polished type of surface texture.

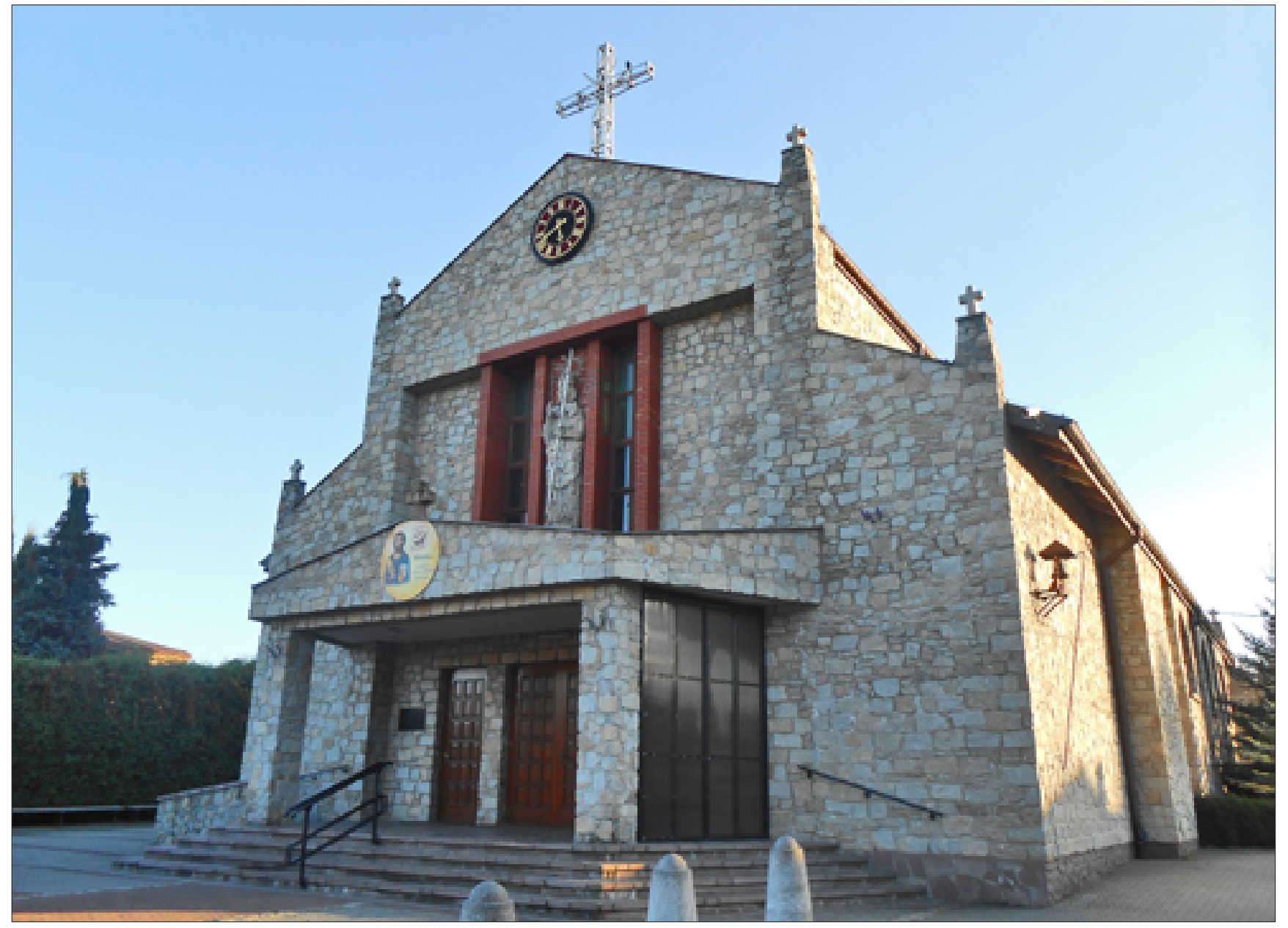

Fig. 7. The St. Stanislaus the Bishop and Martyr church, covered by Strzegom granite - general view, photo A. Śpiewak 


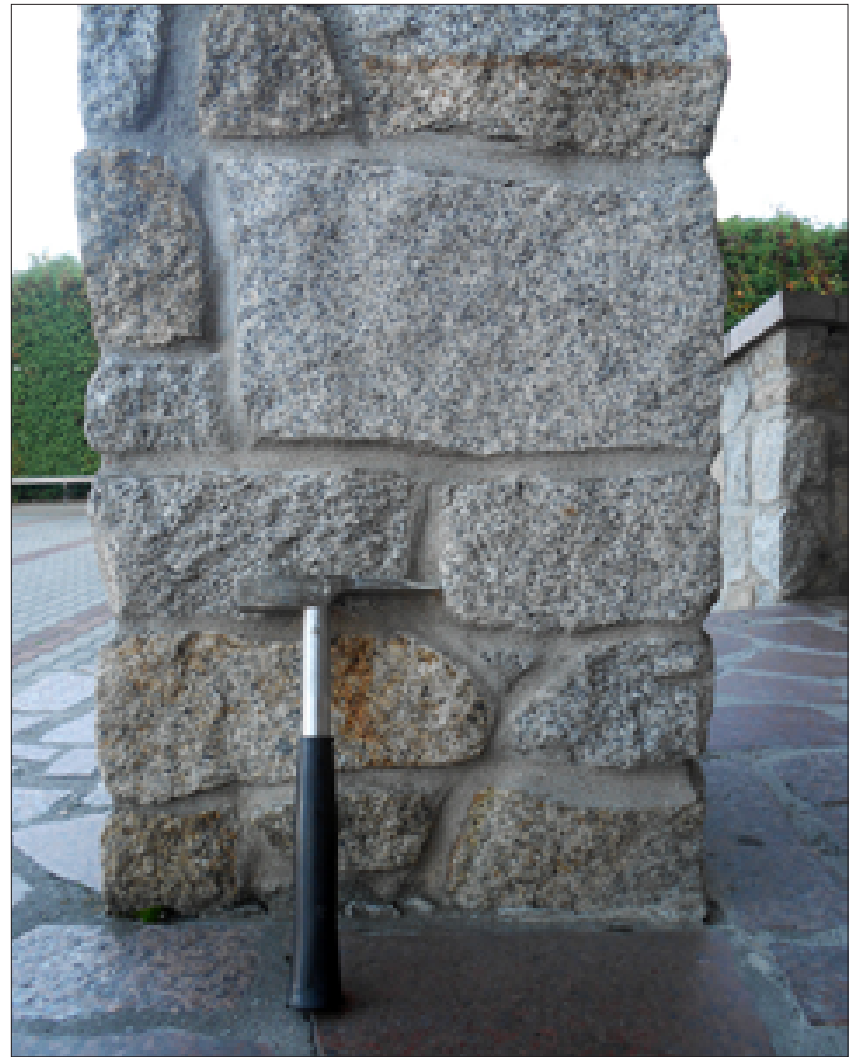

Fig. 8. The front pillar of the St. Stanislaus the Bishop and Martyr church made of Strzegom granite, with a riven surface, photo A. Śpiewak

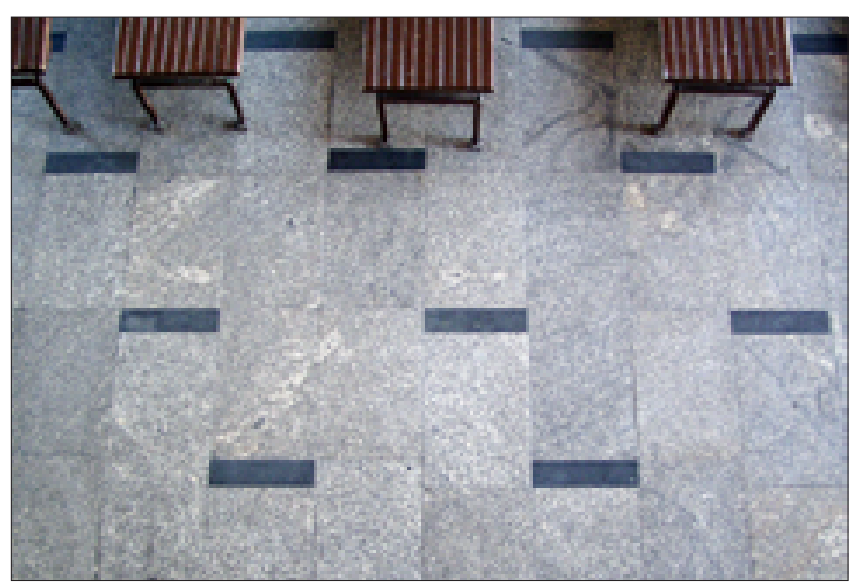

Fig. 9. General view of flooring slabs of Strzegom granite (grey), quartz diorite and monzodiorite of Przedborowa (black) inside the former bus station „PKS Wieluń”, photo A. Śpiewak

The Swedish Black dolerite is exploited in Swedish quarries. The black colour rock is often named „Swede granite”, and it is the most popular of all the Scandinavian granites in the area. The stone has been used almost only in outside and inside memorial plaques and once - in outside facing slabs. The Swedish Black dolerite is seen in either sacral or secular buildings. It exists in the Corpus Christi collegiate, St. Barbara's church, St. Joseph's church, St. Stanislaus's church, the Franciscan monastery and also in Kalisz's Gate or in the commemorative monument of bombing of the All Saints hospital.

The Nero Impala norite comes from quarries in the Republic of South Africa. The rock is distinguished by medium crystalline structure and grey-black colour. The stone displays only the polished type of surface texture in the explored objects. Stone elements, such as vertical and horizontal slabs of the commemorative plaque of a synagogue and pedestal of a cavalry officer Witold Pilecki monument, were made from the Nero Impala norite.

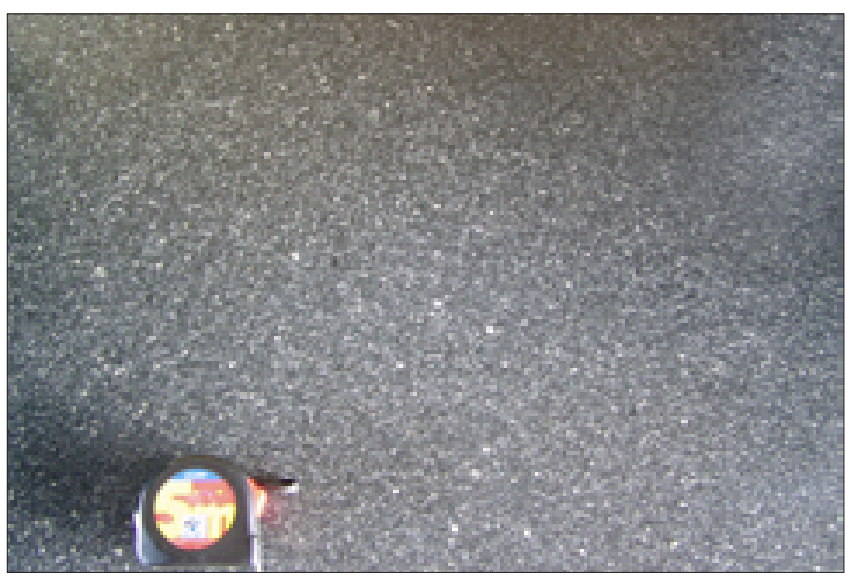

Fig. 10. Flooring slab of quartz diorite and monzodiorite of Przedborowa with a polished surface, photo A. Śpiewak

\section{Marbles}

The Bolechowice limestone is exploited from the limestone deposit, placed in the Świętokrzyskie Voivodeship, in the Chęciny Commune (http://kamienie-budowlane.pgi.gov. $\mathrm{pl}, 2012)$. The rock belongs to rocky limestones, with suitable physical properties of polished surface textures. Due to this property, the Bolechowice limestone is included in a group of „Kielce marbles”. The stone is distinguished by its range of colours from cocoa to brown, stromatoporoids structure, as well as numerous white and pink veins of calcite. The age of the limestone is classified as Devonian. The stone was used in a form of inside facing and flooring slabs. The Bolechowice limestone was also found in the building of the „PKS Wieluń" bus station (Figs 11, 12), as well as in the decorations of the Bank Pekao -Wielun branch.

The Morawica limestone also qualifies in the group of „Kielce marbles”. The Jurassic limestone deposit is located in the Morawica Commune. The rock can be found in variable colours - from cream to beige (four colour variants), with a few purple veins. The limestone is present in the Corpus Christi collegiate, the Franciscan monastery and in the building of the Bank Pekao - branch Wieluń. In all 
of aforementioned places, the Morawica limestone has been used as a building material in the form of inside flooring slabs.

The Dębnik limestone is the next Polish limestone observed during the . This rock is the only recognised limestone deposit situated in Cracow's neighbourhood. The Devonian organic rock deposit is located in the Lesser Poland Voivodeship, in the Krzeszowice Commune. The history of the limestone's exploitation reaches the $14^{\text {th }}$ century. Decorative virtues of the Dębnik limestone have been appreciated, for example, for its black colour, making it aunique raw material. The Dębnik limestone is often named the Dębnik „marble”, because of its characteristic polished surface texture. At the area of exploration, the stone was observed in a form of the memorial plaque in St. Joseph's church and on the epitaph from the $17^{\text {th }}$ century in the Franciscan monastery (Fig. 13).

The Sigismund calcareous conglomerate „Zygmuntówka” owes its name to the column of the king Sigismund III Vasa in Warsaw. The first shaft of the column was made of this stone. A deposit, of whose exploitation has been currently ceased, is located in the Świętokrzyskie Voivodeship, in the Chęciny Commune. The Permian calcareous conglomerate is distinguished by its cherry-maroon colour. In this stone, pebbles of various dimensions are spaced, along with a crystallized carbonate bond of ferruginous pigment (Walendowski, 2009). Additionally, there are calcite veins of white or golden colour. The Decorative virtues of ,Zygmuntówka” are above average and well known. The Sigismund calcareous conglomerate is also classified in the group of „Kielce marbles". The stone is seen in the Corpus Christi collegiate, in the Franciscan monastery and in the building of the Bank Pekao - Wielun branch. The inside flooring slabs and stair slabs were made of this particular stone.

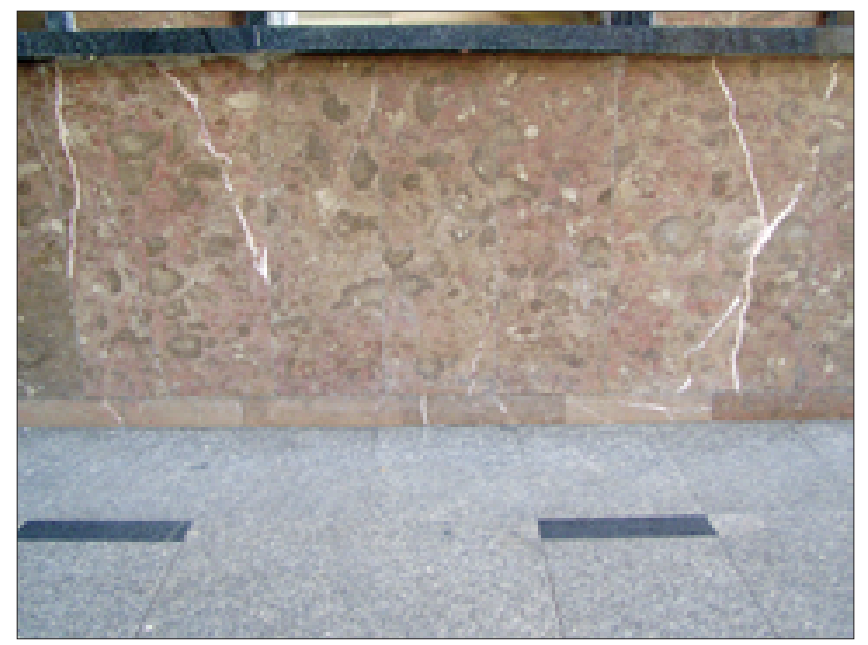

Fig. 11. The former bus station „PKS Wielun” - vertical facing slabs of Bolechowice limestone - part of the wall and floor in the building, photo A. Śpiewak

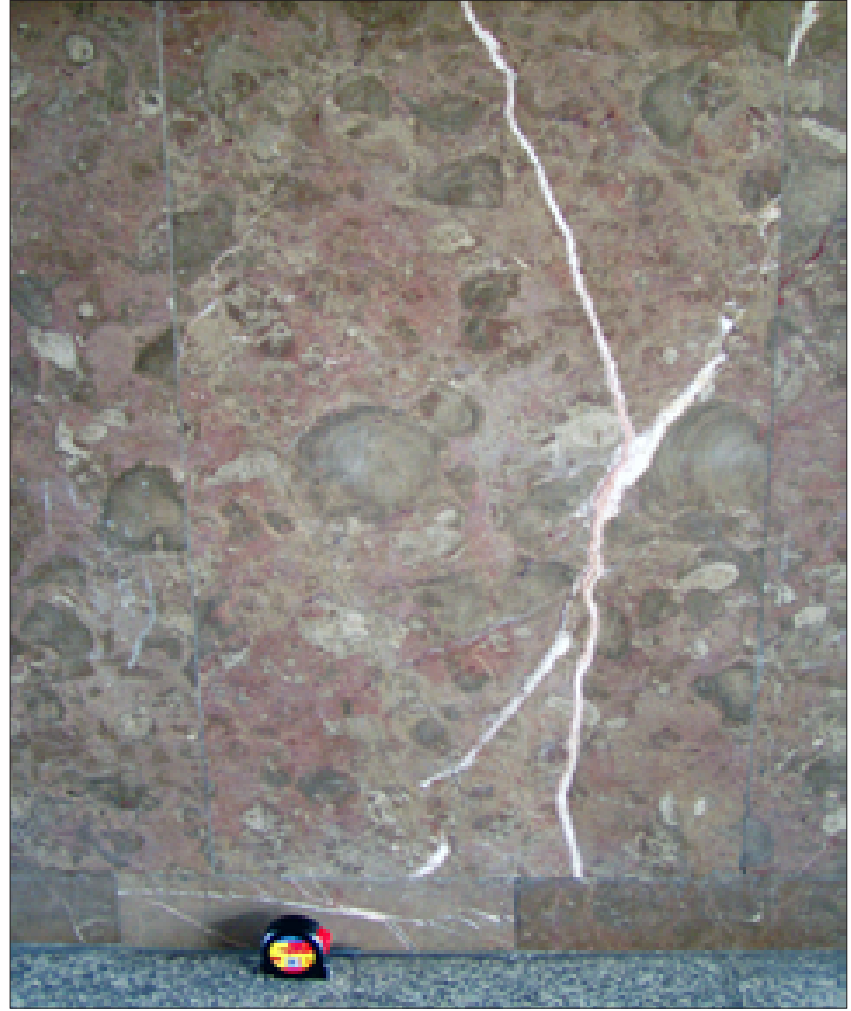

Fig. 12. A stromatoporoid structure with white and pink veins of calcite, in the slab across made of Bolechowice limestone, photo A. Śpiewak

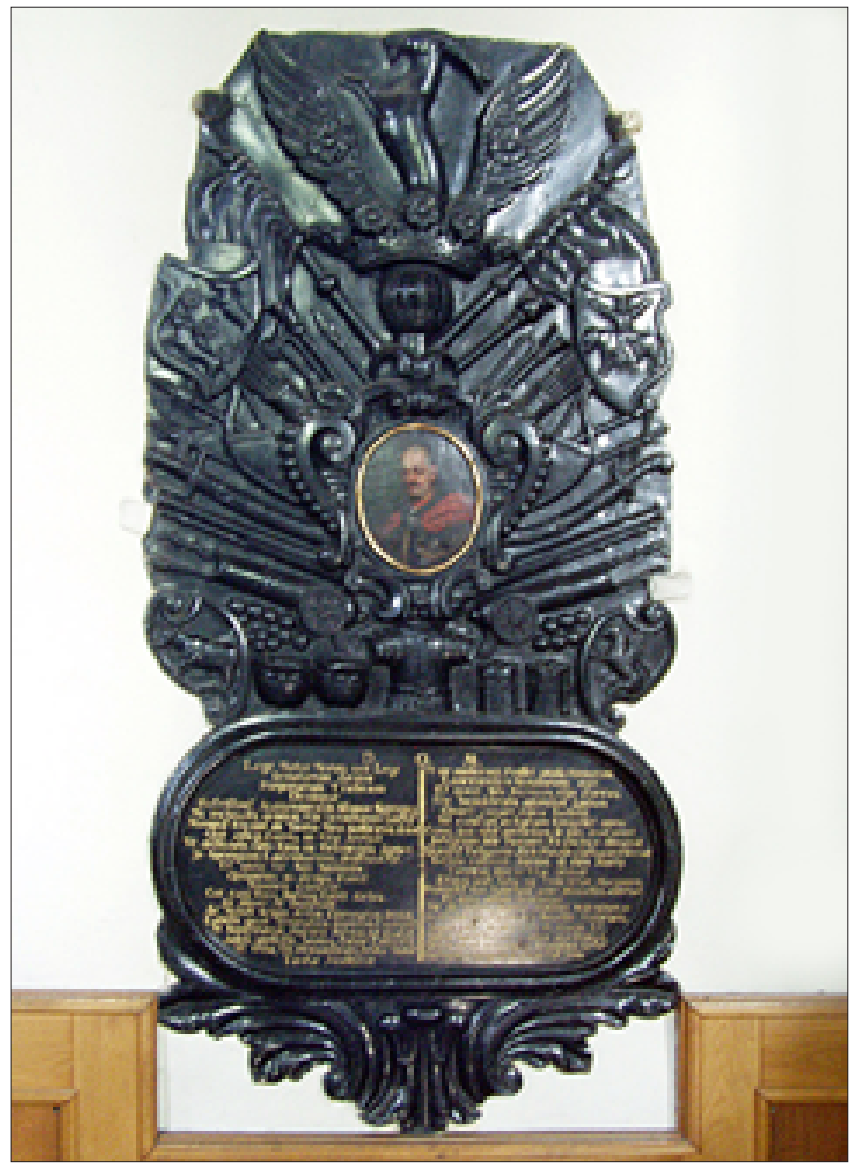

Fig. 13. The nobleman's epitaph in the Franciscan monastery made of Dębnik limestone, photo A. Śpiewak 


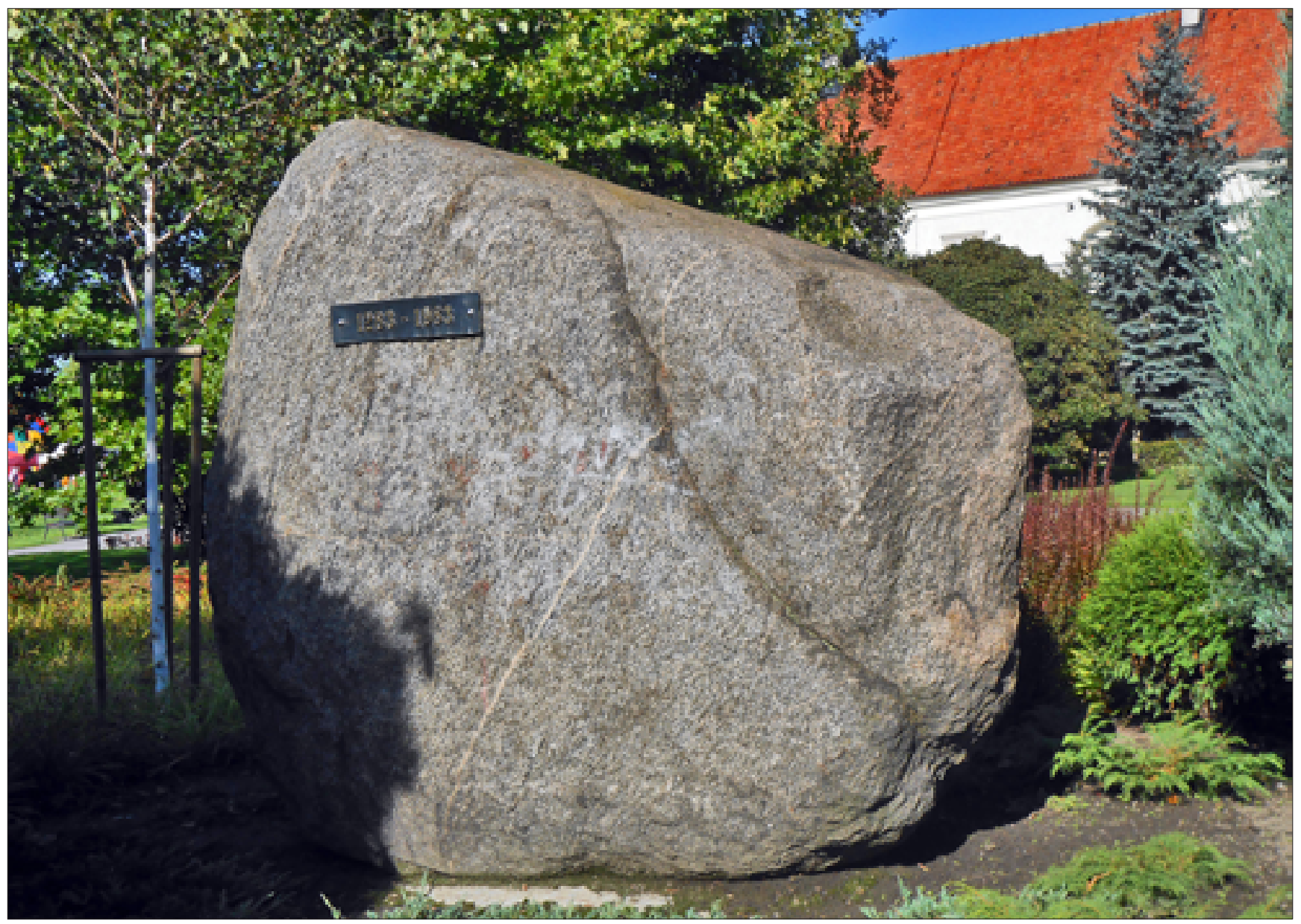

Fig. 14. The erratic - biotite gneiss with aplite veins, photo A. Śpiewak

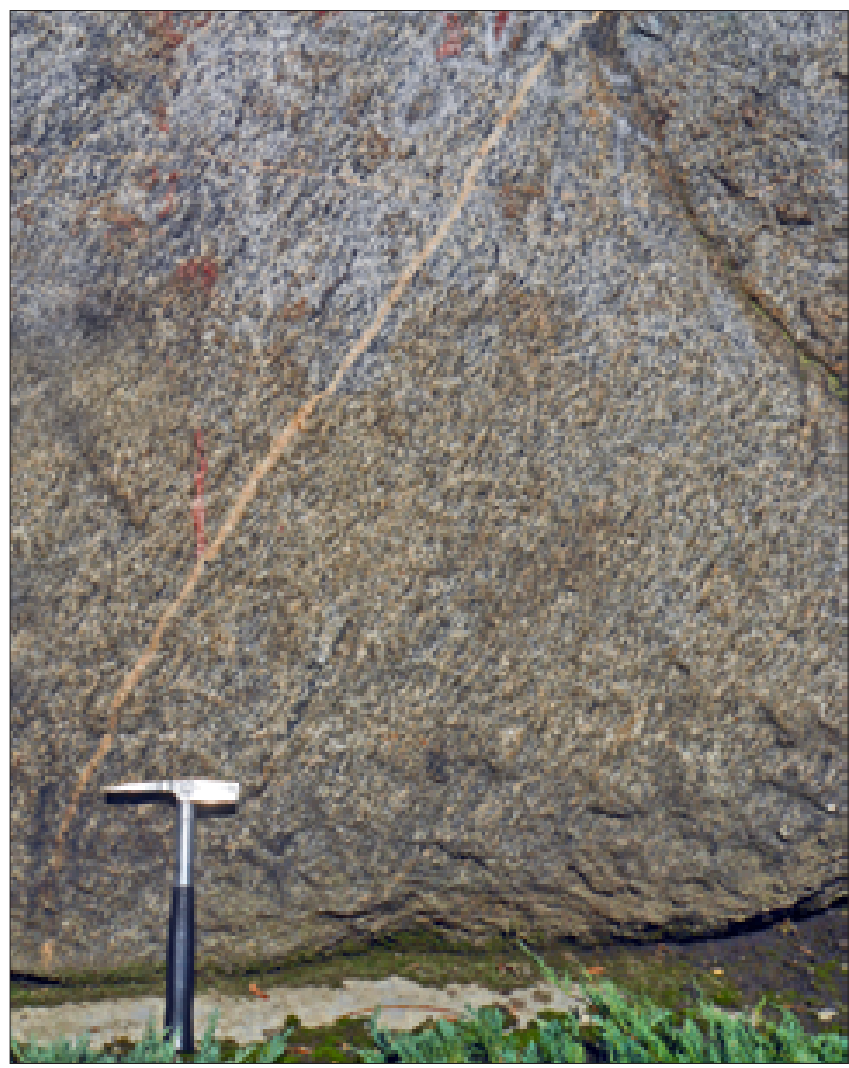

Fig. 15. Aplite vein inside the erratic biotite gneiss, photo A. Śpiewak

\section{Erratics in situ}

The Erratics are often used stone material in the architectural objects of the town, as the area of study has shown. As such, these rocks are easy to possess in this particular area. Large numbers of erratics have been transported to the town and its neighborhood by a Scandinavian continental glacier in the Pleistocene, during the Warta Glaciation.

The biggest erratic (Fig. 14) is placed near the Museum of the Wielun's Land, in the park of the cavalry officer, Witold Pilecki. This is a glacial block of biotite gneiss, which is 7,3 meters in circumference and 2,6 meters high. Additionally, the stone is distinguished by a few parallel aplite veins (Fig. 15). An interesting fact is that a similar erratic is located at the front of the Polish Geological Institue - National Research Institue (PGI-NRI) building in Warsaw, on the Rakowiecka street.

Erratics have been used mainly to build foundations of numerous sacral or secular objects of the town, to make commemorative and decorative building elements, as well as ready-made blocks or aggregates. From the petrographic point of view, erratics are a collection of many various rocks, most often magmatic or metamorphic like granites, gneisses, porphyries etc. 
The erratics have been seen in the Corpus Christi collegiate, St. Barbara's church, the parish church, the Bernardine Franciscan sisters convent, which is the church dedicated to St. Nicholas, the Franciscan monastery and, also, in the town defensive walls, in the Żwirko and Wigura aviation park, in the Witold Pilecki park, in John Paul II Park, as well as in the botanical garden.

\section{Results}

The research was carried out on thirty two architectural objects jointly. It was assumed that an architectural object is a church, building, post-industrial infrastructure object, monument, park or commemorative plaque etc. Among the group of secular objects, twenty five positions were studied. The group of sacral objects numbered $7^{\text {th }}$ in the positions.

On the basis of the research, building stones were recognized by the macroscopic method. In total, fifty six positions of used stone material were observed. Sedimentary rocks formed ten positions, magmatic rocks - twenty four, metamorphic rocks - twenty two. The erratics consisted of both magmatic and metamorphic rocks. From the basic rock groups, the dominance of magmatic rocks and metamorphic rocks is clearly seen.

In order to describe the issue of building stone in architecture from a mathematical point of view, the coefficient of used kinds of stone in architectural objects UKSO (Polish: Wykorzystane rodzaje kamienia w obiektach architektonicznych) was suggested. This coefficient is presented in the first equation (1). The purpose of applying the UKSO coefficient is to be able to present an average of research results and to get a numerical glance on the issue. Such a coefficient may help with the documentation and statistical study of the intensity of stone application in towns. It can also help to display the diversity of stone types in architectural objects.

The exemplary coefficient UKSO has been calculated basing on the data of the research. The estimated value of $\mathrm{UKSO} \approx 1,7$ indicates that approximately almost two kinds of building stones make up every individual architectural object.

$$
U K S O=\frac{R}{N}
$$

where:

$R$ - number of all types of rocks, $N$ - number of all architectural objects.

$$
U K S O=\frac{55}{32} \cong 1,7
$$

\section{Conclusions}

On the basis of the research, fifty six kinds of building stones were recognized. Various types of stones are observed in churches and among secular buildings - in Wieluńs botanical garden, as well as in the Bank Pekao - Wieluń branch. The largest diversity of stones was observed in the Corpus Christi collegiate.

National building stone makes up over fifty percent of all kinds of used stone as raw material. Of all Polish stones, the local stones were used most frequently (the erratics, the Middle Jurassic and Upper Jurassic limestones, the Raciszyn limestone, the „travertine” and the ferruginous sandstone). Looking at the rest of Polish stones, it is noticeable that only the Strzegom granite was used on a similar level.

The degree of use of foreign rocks is clearly different. The study showed that the largest share in building elements is taken by the Swedish Black dolerite, the "Swede granite”. The rest of the foreign stones were used at a low scale.

From the petrographic point of view, the number of types of ,granites” and „marbles” is very similar. The next position is taken by sandstones. Different types of other rocks can be found rarely. This is the reason they are at the end of the list. The Middle Jurassic and Upper Jurassic limestones, as well as the erratics dominate as the most often used stone materials.

The building rock elements were mostly made up of various shape and size blocks and cut stones, flooring slabs, stair slabs, commemorative plaques and outside or inside facing slabs. It is noticeable that the stone mostly had polished or riven type of surface texture.

It seems that such a large collection of numerous kinds of building stones in the researched area, and especially the local stones, are both of considerable potential and can be used for the development of geotourism. This is particularity true for urban geotourism. This would make it possible to promote Wielun in the country, and to provide an opportunity to take a glance at the architecture of the town, its history and heritage from a different perspective.

\section{References}

Janus K., Obarowska D., 2011. Załęczański Park Krajobrazowy i okoliceWyżna Wieluńska (część północna Jury Polskiej), mapa geoturystyczna $1: 50$ 000. Państwowy Instytut Geologiczny - Państwowy Instytut Badawczy, Warszawa.

Kondracki J., 2002. Geografia regionalna Polski. Wydawnictwo PWN, Warszawa.

Lorenc M.W., Mazurek S., 2007. Wykorzystać kamień. Studio Jasa, Wrocław.
Prell M., Zagożdżon K.D., 2011. Kamień naturalny w wybranych obiektach komercyjnych Wrocławia. Prace Naukowe Instytutu Górnictwa Politechniki Wrocławskiej, 133 (40): 109-121.

Rajchel J., 2004. Kmienny Kraków, spojrzenie geologa. Akademia Górniczo-Hutnicza, Uczelniane Wydawnictwa Naukowo-Dydaktyczne AGH, Kraków.

Rajchel J., 2008. Stony Cracow: geological valors of its architecture. Przegląd Geologiczny, 56 (8/1): 653-662. 
Rodrigues M.L., Machado C.R., Freire E., 2011. Geotourism routes in urban areas: a preliminary approach to the Lisbon geoheritage survey. GeoJournal of Tourism and Geosites, Year IV, 8 (2): 281-294.

Walendowski H., 2009. Zygmuntówka. Minimonografie polskich kamieni budowlanych. Nowy Kamieniarz, 38 (2): 58.

Zagożdżon P.P., 2009. Kamień w architekturze a „,architektura” kamienia. Nowy Kamieniarz, 43 (7): 64-74.

Zagożdżon P.P., Śpiewak A., 2011. Kamień w architekturze a geoturystyka miejska - przykłady z terenu Wrocławia. Prace Naukowe Instytutu Górnictwa Politechniki Wrocławskiej, 133 (40): 123-143.

\section{Websites}

http://kamienie-budowlane.pgi.gov.pl, website of building stones in Poland, PGI-NRI, 2012.

http://mapy-geol.pgi.gov.pl/, website of Polish Geological Maps, PGI-NRI, 2011.

http://maps.google.pl/, 2012.

http://www.um.wielun.pl/, website of Wieluń Municipal Office, 2012. 